\title{
ISLAND POPULATIONS OF PHYSALAEMUS PUSTULOSUS: HISTORY INFLUENCES GENETIC DIVERSITY AND MORPHOLOGY
}

\author{
Kathrin P. Lampert ${ }^{1,3,5}$, Ximena E. Bernal ${ }^{1}$, A. Stanley Rand ${ }^{2,4}$, Ulrich G. Mueller ${ }^{1,2}$, \\ and Michael J. Ryan ${ }^{1,2}$ \\ ${ }^{1}$ Section of Integrative Biology, 1 University Station C0930, University of Texas, Austin, TX, 78712, USA \\ ${ }^{2}$ Smithsonian Tropical Research Institution, Apd. 2072, Balboa, Panama
}

\begin{abstract}
AвsтRACT: Island populations are convenient models of large-scale evolutionary processes and provide natural replicates of evolution. Recently founded island populations also provide an opportunity to study populations derived from few individuals, and these populations, in particular, often show rapid diversification. Here we report morphological and molecular data for the túngara frog, Physalaemus pustulosus, from three different islands of Panama: Coiba, a large island with a rather old túngara frog population; Isla Grande, a small island with a fairly recent population of túngara frogs, and Barro Colorado Island (BCI), a large island artificially created by flooding to form the Panama Canal about 100 yr ago. Frogs from the two natural islands, but not those from BCI, were significantly larger than frogs from the mainland, which is consistent with the "island rule" stating that small species on islands tend to be larger while large species tend to be smaller than their mainland relatives. Genetic diversity, estimated from allelic richness at seven microsatellite loci, was drastically reduced in the Isla Grande population, whereas heterozygosity was not reduced. This result suggests that this island population of frogs went through a severe and recent bottleneck.
\end{abstract}

Key words: Dispersal; Genetic drift; Heterozygosity; Inbreeding; Microsatellite markers; Population genetics

ISLAND populations provide naturally-occurring examples of evolution (Mayr, 1963) and, more specifically, allow the study of dispersal, adaptive radiation and founder effects in a limited space and at very small time scales (Grant, 1998; Grant, 2003). New populations on islands typically experience a genetic bottleneck (Avise, 1994) because colonization usually involves few individuals (Whittaker, 1998). Because island populations often are small and isolated from one another and from mainland source populations, rapid evolution through genetic drift and selection is possible (Barton, 1998). Anthropogenic disturbance of continuously distributed populations also can lead to small and fragmented populations similar to the conditions on islands (Andersen et al., 2004; Seppä and Laurila, 1999). Loss of genetic diversity, however, may reduce the potential of small populations to respond to selective pressures (Allendorf and Leary, 1986), and increased inbreeding may reduce

\footnotetext{
${ }^{3}$ Present Address: University of Würzburg, Department of Physiological Chemistry I, Biozentrum, Am Hubland, 97074 Würzburg, Germany.

${ }^{4}$ Posthumous.

5 CORRESPONDENCE: e-mail, kathrin.lampert@biozentrum. uni-wuerzburg.de
}

population viability (Leberg, 1990). Several amphibian species have been shown to suffer from inbreeding and reduced fitness (Lesbarrères et al., 2005; Reh and Seitz, 1990).

Investigating island populations of frogs can contribute to our understanding of evolutionary processes such as adaptation and radiation and allows insights into conservation issues such as habitat fragmentation. Neutral markers, such as microsatellite markers, are useful tools to analyze recent genetic variability in populations as well as tracking historical events such as bottlenecks and founder effects (Clegg et al., 2002; Tarr et al., 2000). Here we utilize microsatellite markers to compare some population genetic parameters of túngara frogs, Physalaemus pustulosus, on three islands with different histories of colonization.

Túngara frogs are abundant throughout the dry lowland forest in Middle America and inhabit a wide range of habitat types (Ryan, 1985). In addition, they are a model system for the study of sexual selection and the evolution of communication (review in Ryan, 1998; Ryan and Rand, 2003) and have been subjected to a number of studies of genetic variation (Lampert et al., 2003; Pröhl et al., 2006; Ryan et al., 1996; Weigt et al., 2005). 
Population genetic studies on túngara frogs revealed high levels of differentiation at large and small geographic scales, leading to the conclusion that túngara frogs do not disperse over wide distances. In a former study, we also found that túngara frogs do not discriminate against closely related genotypes for mating (Lampert et al., 2006). Probably due to large population size and high mortality rates, however, closely related or inbred individuals were rarely found in the mainland populations investigated by Lampert et al. (2006).

Túngara frogs also occur on a number of islands in Panama. We assumed that island populations of túngara frogs should be more closely related than mainland populations as they are often derived from few founding individuals, population sizes are small and gene flow is limited. We compared three different island populations to each other and to various mainland populations. Our main questions were: Do island populations of túngara frogs indeed show signs of a bottleneck? Do we find inbreeding on islands? Do differences in the islands' history correlate with differences in population genetics in túngara frogs? To address these issues we examined molecular and morphological characteristics of túngara frogs from three islands and four mainland populations.

\section{Material and Methods Sampling Sites}

We analyzed three islands (Coiba Island, Isla Grande, and Barro Colorado Island) that were different in size and other characteristics. The Pacific island Coiba is large $\left(\sim 536 \mathrm{~km}^{2}\right)$ and lies $22.5 \mathrm{~km}$ southwest of the mainland shore. It is of volcanic origin and presumably rose above sea level towards the end of the tertiary. Coiba was used as a prison island until 1993 and still has few human residents. The túngara frog population on Coiba island has been known for at least $50 \mathrm{yr}$ (A. S. Rand, personal communication), but we have no means to estimate when colonization might have first taken place. Isla Grande is a small Atlantic island $\left(\sim 7 \mathrm{~km}^{2}\right)$ and is very close to the mainland $(500 \mathrm{~m})$. It is a popular tourist destination. The frog population on Isla Grande was founded some time in the last
12 yr (A. S. Rand, personal communication). Barro Colorado Island (BCI) is an artificial island of $15 \mathrm{~km}^{2}$ that was created when this hilltop was isolated from surrounding land in 1913 with the flooding of the Chagres River forming Lake Gatun when the Panama Canal was formed. Thus, the BCI population of túngara frogs has been present for nearly $100 \mathrm{yr}$, but the presence of túngara frogs at that locality, e.g., prior to when it was an island, might have a much longer history. The minimum distance of BCI to the mainland shore is about $500 \mathrm{~m}$. The islands are not quite comparable because two of them are oceanic islands separated by saltwater from the mainland, whereas BCI is separated by freshwater and is an island surrounded by mainland populations. Independent of the distances between mainland and respective island, gene flow from mainland populations to BCI therefore can be expected to be higher compared to the gene flow to the other two islands.

\section{Animals and Sampling}

Physalaemus pustulosus is a small frog (snout-vent length about $35 \mathrm{~mm}$ ) from the family Leptodactylidae. Tadpoles need about four to six weeks to metamorphose and can start reproduction two to three months after metamorphosis. Animals in captivity can reach several years of age but in the field predation pressure reduces their lifespan to less than a year.

Animals were collected on 6-7 July 2003 from a breeding pond on Isla Grande $\left(9^{\circ} 37^{\prime} \mathrm{N}\right.$ $79^{\circ} 34^{\prime} \mathrm{W}-n$ (both sampling trips) $=31$ ). Additional individuals from this site and from a breeding pond close to the shore on the adjacent mainland (La Guaira - $9^{\circ} 37^{\prime} \mathrm{N} 79^{\circ}$ $34^{\prime} \mathrm{W}-n=17$ ) were collected on 2 August 2003. In addition, frogs were collected from a breeding pond on Coiba Island (Pacific side $\left.-7^{\circ} 30^{\prime} \mathrm{N} 81^{\circ} 40^{\prime} \mathrm{W}-n=6\right)$ on 12 July 2003. Animals from BCI $\left(9^{\circ} \mathrm{N} 79.45^{\circ} \mathrm{W}-n\right.$ $=61$ ) and the closest mainland sites, Bohio $(n=19)$ and Gigante $(n=19)$, were collected from 1-5 July 2003. Animals from the mainland Gamboa population $\left(9^{\circ} 7^{\prime} \mathrm{N}\right.$ $\left.79^{\circ} 42^{\prime} \mathrm{W}-n=48\right)$ were collected from 15-30 July 2003 (Fig. 1). All animals were collected from a single breeding pond on the 


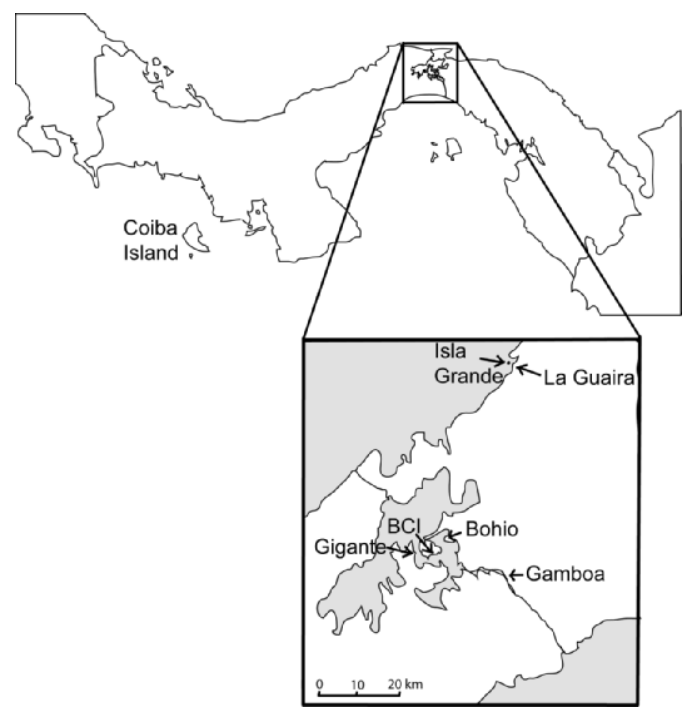

FIG. 1.-Sampling sites.

island investigated. As more than $95 \%$ of all individuals collected were males, only male frogs were used for both the measurements of size and the genetic analyses $(n($ total $)=201)$. Genetic results were compared to males of a mainland population of túngara frogs from Gamboa (Fig. 1). All frogs were marked with toe-clips (two toes per individual) to prevent recapture and the clipped toes were used for genetic analyses. Frogs were measured [snoutvent length (SVL)] and immediately released at the point of capture. Tissues were stored in $20 \%$ ethylenediaminetetraacetic (EDTA)/sarcosyl buffer until processing in the laboratory at the University of Texas at Austin.

\section{Sample Processing}

DNA was extracted using the DNeasy tissue kit (Qiagen). Polymerase chain reactions (PCR) were performed on seven microsatellite loci (CA120, CA298, A311, A1911, C3011, ATG159, ATG263) originally developed by Pröhl et al. (2002). PCRs were performed following the protocol by Pröhl et al. (2002) except for denaturing, annealing and elongation times that were each reduced to $30 \mathrm{~s}$. One primer of each pair was labeled with fluorescent dye to allow fragment size analysis on an ABI Prism ${ }^{\circledR} 3100$ capillary sequencer (Lampert et al., 2003).

\section{Data Analyses}

Arlequin version 2.000 (Schneider et al., 2000) was used to determine allele frequencies and for assessing population differentiation by $F$-statistics. A Mantel test with 1000 iterations was used to test for isolation by distance (Liedloff, 1999). Fstat (Goudet, 2002) was used for determination of Fis values and to calculate allelic richness for the minimum number of individuals sampled per population $(=6)(\mathrm{El}$ Mousadik and Petit, 1996). We used Relatedness 5.0.8 (Queller and Goodnight, 1989) to calculate individual relatedness. For the relatedness calculations allelic frequencies from a mainland population were used as a reference. SPSS 12.0.2 was used for comparisons of individual relatedness and morphology between sites (Kruskal-Wallis ANOVA followed by a posthoc Scheffé test). We used the program Bottleneck (Piry et al., 1999) to test for heterozygote deficiencies and excess under the assumption of the infinite allele model (IAM) or stepwise mutation model (SMM). Heterozygote excess is expected in populations that experienced a recent bottleneck because population reduction leads to a faster loss of allelic richness than of heterozygosity (Wang et al., 2005). In addition we used the M-ratio test (Garza and Williamson, 2001) to test for recent bottlenecks in the island populations.

\section{RESUlTS}

\section{Morphology}

Morphology differed between sites (KruskalWallis- $H: \mathrm{Chi}^{2}=71.695$, df $\left.=6, P<0.001\right)$. Frogs from Coiba were larger than frogs from any other site (Scheffé Posthoc test all $P<$ 0.00001 ). Second largest were frogs from Isla Grande. Although those were smaller than frogs from Coiba, they were larger than frogs from any other site (all $P<0.0001)$. Frogs from Gamboa and BCI were the smallest but did not differ in size from Gigante or Bohio frogs. Frogs from La Guaira were slightly larger than frogs from Gigante and Bohio and therefore larger than frogs from Gamboa $(P=0.001)$ and BCI $(P=0.03)$ (Fig. 2A).

\section{Genetic Variability}

Microsatellite loci varied in the number of alleles identified. The most variable locus was 

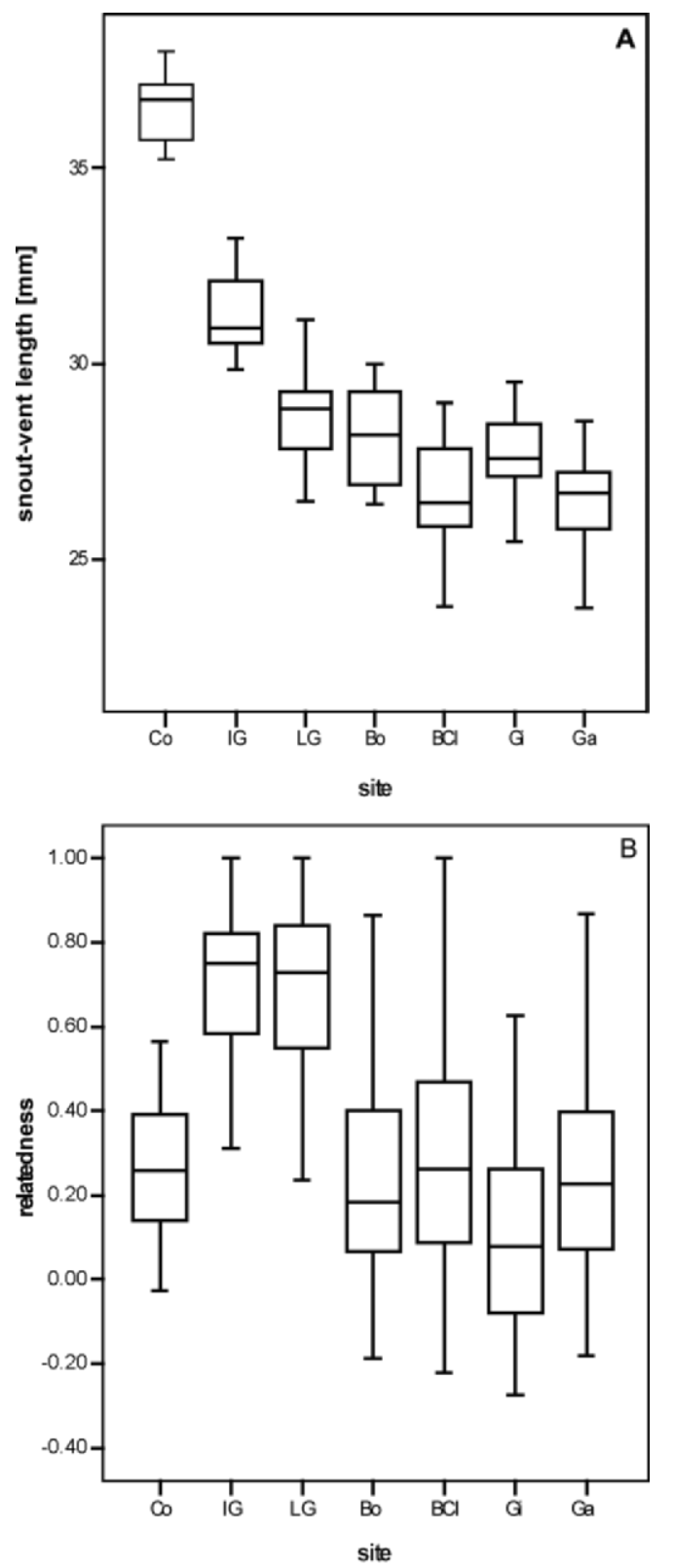

FIG. 2.-Box plots for morphology (snout-vent length) and relatedness at the different sites sampled. Given are median, inter-quartile range and $95 \%$ confidence intervals for different sites. (C - Coiba island, IG - Isla Grande island, LG - La Guaira, B - Bohio, BCI - Barro Colorado island, Gi - Gigante, Ga - Gamboa). (A) Size of animals found in the different locations. (B) Individual relatedness within the different populations.

CA298 with 45 alleles in 201 individuals, followed by C3011 with 44 alleles in 201 individuals. Sites differed greatly in the number of alleles found and allelic richness varied accordingly. Gigante showed the highest allelic richness $6.6+/-1.68$ followed by Gamboa $(6.5+/-1.09)$, Bohio $(6.2+/-1.34)$, BCI $(5.8+/-1.28)$ and Coiba $(5+/-2.45)$.

The lowest allelic richness showed La Guaira (3.04 +/- 1.45) and Isla Grande (2.5 +/0.91) (Table 1). Also, allelic distribution varied widely between populations. For example, Isla Grande and La Guaira were monomorphic for locus CA298 while Coiba was monomorphic for locus A311. Overall Gamboa showed the most variation with a mean of 16.3 alleles per locus and a maximum number of 21 alleles in locus A1911 and in locus C3011 in 48 individuals. Isla Grande was the least variable site with a mean of 2.71 alleles per locus and a maximum of four alleles in locus C3011 and ATG263 (Table 1). Isla Grande and La Guaira exhibited much lower allelic diversity than expected from their sample size (Fig. 3). Fis values also varied widely between populations and loci. Levels of inbreeding were highest in Coiba (0.233), lowest on Isla Grande $(-0.08)$ and intermediate $(0.09$ to 0.19$)$ at the other sites (Table 1 ).

Individual relatedness (Queller and Goodnight, 1989) was highest within the Isla Grande population (0.72) and almost as high in the La Guaira population (0.70). Individuals from Gigante were the least related (0.13). Individuals within BCI and Coiba were slightly closer related to each other than individuals from Bohio and Gamboa (Table 2 diagonal, Fig. 2B). On the inter-population level, the frogs from Isla Grande and $\mathrm{La}$ Guaira seemed to be closely related to each other $(0.715)$, while all other site combinations showed very low levels of individual relatedness $(-0.085$ to 0.193 ) (Table 2 below diagonal).

To analyze the genetic differentiation between populations we calculated Fst values (Table 2 above diagonal). Even though only low levels of genetic differentiation were detected (0 to 0.02), we found significant differentiation between La Guaira and Isla Grande and the rest of the populations investigated (Table 2). Although the Fst differences between sites seemed to broadly coincide with geographic distances, no significant isolation by distance could be detected 


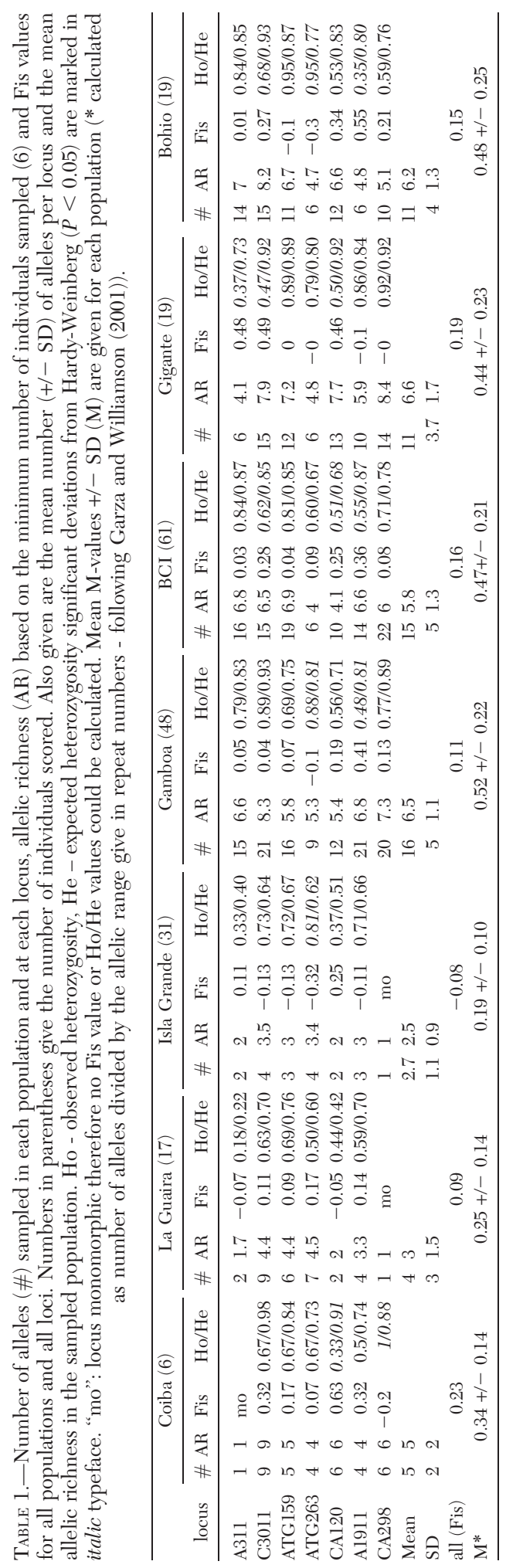

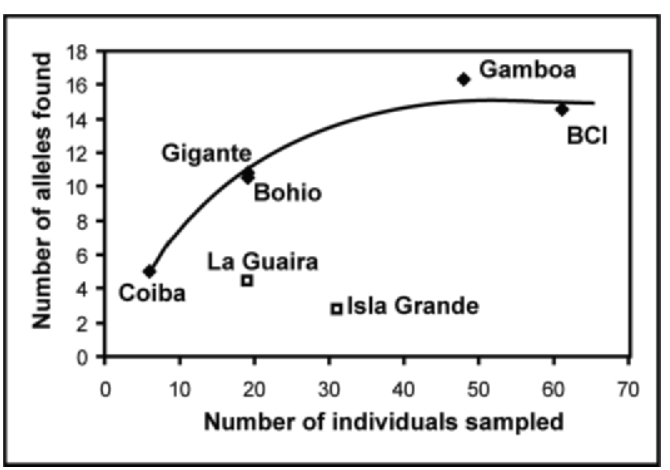

FIG. 3.-Correlation between the number of individuals sampled and the mean number of alleles found in a population. The populations of La Guaira and Isla Grande (open squares) clearly show fewer alleles than expected for their sample size. The line represents a logarithmic function that fits the general trend of the data.

(Mantel test: $g=-0.3046, Z=73.1655, r=$ $-0.0728, P=0.42$ ).

The program Bottleneck (Piry et al., 1999) detected a significant heterozygote excess (6 out of 6 loci) in the Isla Grande population under the IAM as well as the SMM model ( $P$ (both models $)=0.008)$. All other populations showed heterozygote deficiencies rather than heterozygote excess. The $\mathrm{M}$ ratio test ( $\mathrm{Ta}-$ ble 1) revealed a strong bottleneck in Isla Grande $(M=0.19)$ and a slightly weaker bottleneck in the La Guaira population $(M=$ 0.25 ). It could still detect a bottleneck in the Coiba sample $(M=034)$. The other populations that were considered to be in equilibrium showed $\mathrm{M}$ values between 0.44 and 0.52 (Table 2).

\section{DisCusSION}

The morphological as well as genetic results found in this study are consistent with the very different island histories. The túngara frog population on the very young, human-made island of Barro Colorado is not very different in allelic diversity or body size from the two populations we sampled on the nearby mainland. We assume this is because BCI was not colonized as the other islands, but had a resident population of túngara frogs that was isolated from the mainland less than a century ago during the building of the Panama Canal. Also, BCI is very close to and 


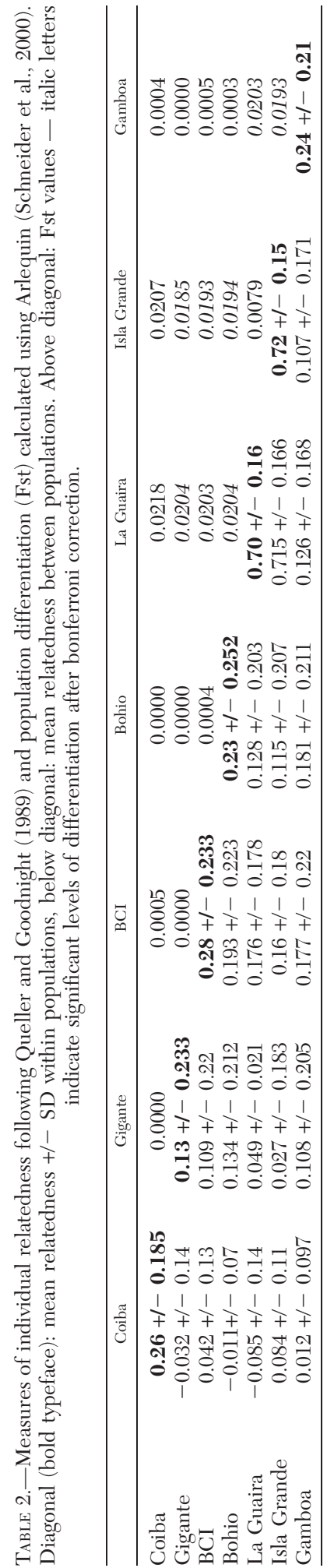

even surrounded by the mainland, probably receiving migrants from all sides rather than the other islands where migrants may come only from one direction. In addition BCI is separated from the mainland by fresh rather than saltwater. Even though we found that the nearby Chagres River poses a barrier to migration to populations on either side of it (Lampert et al., 2003) salt water should be a much more effective barrier than fresh water.

Frogs from Coiba island showed intermediate levels of allelic and genotypic diversity. These individuals were fixed for one microsatellite locus (A311) that was very variable in other populations, and individuals in the Coiba population were rather inbred. A bottleneck was detected with the M-ratio test but could not be detected using the genetic diversity as implemented in the bottleneck program probably because the colonization did not happen very recently (more than $50 \mathrm{yr}$ ago) or because the bottleneck was not severe. Unfortunately, sample size in Coiba is low and all interpretations should be made cautiously.

The most striking finding for Coiba, however, is the large size of the individuals measured, although we again caution that the sample size is small. These results are, however, consistent with 'island gigantism' described in many species (Castellano and Giacoma, 1998; Grant, 2001; Robinson-Wolrath and Owens, 2003). This "island rule" was articulated earlier by Van Valen (1965) and can be applied to at least some invasive species (Campbell and Echternacht, 2003). The large size of the Coiba frogs might therefore be indicative of the population being isolated for some time. The actual cause of the island gigantism, however, cannot be determined.

Whereas the allelic diversity for all but one monomorphic locus in Coiba equaled the variability found in the Gamboa mainland population, the Isla Grande population showed very few alleles per locus. In fact, we did not find more than four alleles for any of the loci we investigated. The microsatellite markers used in this study have been shown to be very variable and informative at both large (Pröhl et al., 2006) and small geographic scales (Lampert et al., 2003). The low level of diversity detected 
on Isla Grande is therefore surely not an artifact of overall low microsatellite diversity. Null alleles can be excluded as a main source of low allelic diversity as those would lead to a heterozygote deficiency rather than excess due to the inadvertent classification of heterozygote as homozygote individuals. There is consensus that bottlenecks have much more severe effects on allelic diversity than on heterozygosity (Leberg, 1992; Spencer et al., 2000; Williamson-Natesan, 2005). We therefore conclude that the low allelic diversity in the túngara frogs on Isla Grande is most likely due to a severe recent bottleneck. This inference was confirmed by the M-ratio test revealing a severe bottleneck for Isla Grande.

As túngara frogs are diploid and therefore have two alleles per gene locus, the maximum number of four alleles per locus within the population suggests that all frogs on Isla Grande might have been derived from a single invasion event either by a single pair of frogs or, perhaps more likely, a single clutch of eggs. The population closest to Isla Grande, La Guaira, also shows rather few alleles, less than all other populations but a few more than Isla Grande. The alleles present at the La Guaira population are very similar to the alleles found on Isla Grande. Relatedness estimates were around 0.7 within the Isla Grande and the La Guaira site as well as between these sites. This high value of relatedness suggests that individuals from those sites could be full siblings (Blouin et al., 1995). Interestingly, Isla Grande and La Guaira were monomorphic for one locus (CA 298), while Coiba was monomorphic for another locus (A311). This result could be a consequence of a founder effects on both islands (Hartl and Clark, 1997), because the genetic consequences of a founder effect include substantial loss in genetic diversity (Pruett and Winker, 2005). It is possible, however, that the frogs on Isla Grande came from the La Guaira population. As the La Guaira population also shows some reduced allelic diversity, it seems likely that this frog population also was introduced, although it is possible that the low allelic diversity is due to a severe reduction in population leading to a bottleneck. Introduction most likely happened anthropogenically, perhaps the frogs were transported with building material as túngara frogs often breed in short lived sandy puddles and in heavily disturbed areas such as parking lots or construction sites.

Even though animals on the islands seem to be rather closely related, inbreeding (homozygosity) could hardly be detected. In fact a clear heterozygote excess was detected for Isla Grande. The possibility that this heterozygote excess is due to a recent bottleneck (Wang et al., 2005) needs to be investigated more closely. In very severe cases of bottlenecks, such as founding by a single pair, heterozygosity should in fact be reduced (Leberg, 1992). The excess of heterozygotes might point to the possibility that frogs from Isla Grande preferably mate with individuals that are either heterozygous, in general, or have different alleles than the partner in particular. Both possibilities suggest that there could be inbreeding avoidance in mating in this population, although there was no evidence for this in Gamboa populations (Lampert et al., 2006). Another explanation might be early death in homozygous individuals resulting in heterozygotes as only surviving adults.

Even though Isla Grande frogs were significantly smaller than frogs from Coiba they were significantly larger than frogs from all other sites. This might reflect the fact that the population of túngara frogs on Isla Grande has not been isolated for quite as long as the Coiba population but is already diverging from the mainland populations following the "island rule". This finding is striking as the Isla Grande population is presumably very young and the changes in morphology must therefore have happened in a very short time span in only a few generations.

Comparing the different populations, we found very low levels of genetic differentiation even though some of the populations were about $300 \mathrm{~km}$ apart and showed very different allelic patterns. Fst values in this study ranged between 0.0 and 0.02 which was within the range of a study examining differentiation at a much smaller scale (range $10 \mathrm{~km}$; Fst values between 0 and 0.039) (Lampert et al., 2003). A larger-scale genetic study working in geographic scale similar to the one in this study (Pröhl et al., 2006) found much higher levels 
of genetic differentiation in Costa Rica (Fst for the Southern group: 0.012-0.26). An even larger-scaled $(5000 \mathrm{~km})$ study on genetic variability in túngara frogs using mitochondrial as well as allozyme data also revealed high levels of genetic diversity between populations that were several hundred kilometers apart (Weigt et al., 2005). With the exception of this island study, all studies investigating genetic diversity in túngara frogs found a significant isolation by distance in túngara frogs. Obviously, our results are based on rather low and very different sample sizes per site, which influences the calculation of genetic differentiation. The observed differences in Fst values to the mainland studies must therefore be interpreted very cautiously. These comparisons reveal, however, that the island populations of túngara frogs are different from the mainland populations and need to be investigated more thoroughly.

\section{Conclusions and Research Outlook}

Populations of túngara frogs on all islands surveyed differed in genetic diversity as well as in morphology (size) relative to mainland populations and seem to represent different types and stages of colonization. Further studies of allelic and genotypic diversity could provide insights into founding events and mechanisms stabilizing newly emerging populations. They could also provide information about the effects of inbreeding and on ecological/nutritional differences between locations. In addition, future research should focus on mate choice within these populations. Population-specific differences in discrimination against closely related individuals as mating partners might be possible. As body size critically influences male mating call traits, a study focusing on the shifts in male call traits due to larger size and in the corresponding female preferences might help us to gain insight into mating signal and preference evolution.

Acknowledgments.-We thank Autoridad Nacional del Ambiente of the Republic of Panama and STRI for research and export permits. STRI provided invaluable logistic support. C. Ulloa and O. Crino helped gather data in the field. We are especially indebted to H. Pröhl, who developed the microsatellite primers used in this study. This work was supported by the German Science Foundation (DFG) LA 1382/2-1 (KPL), by NSF grants
IBN-0078184 to MJR, D. Cannatella, and W. Wilczynski, IBN-9816564 to MJR, and by an NSF-CAREER award DEB-9983879 to UGM. The research presented complies with the current laws of the countries in which it was performed.

\section{REFERENCES}

Allendorf, F. W., And R. F. Leary. 1986. Heterozygosity and fitness in natural populations of animals. Pp. 57-76. In M. E. Soulé (Ed.), Conservation Biology: The Science of Scarcity and Diversity. Sinauer Associates Inc., Sunderland, Massachusetts, U.S.A.

Andersen, L. W., K. Fog, and C. Damgandd. 2004. Habitat fragmentation causes bottlenecks and inbreeding in the European tree frog Hyla arborea. Proceedings of the Royal Society of London B 271:1293-1302.

Avise, J. C. 1994. Molecular Markers, Natural History and Evolution. Chapman and Hall, New York, New York, U.S.A.

Barton, N. H. 1998. Natural selection and random genetic drift as causes of evolution on islands. Pp. 102-123. In P. R. Grant (Ed.), Evolution on Islands. Oxford University Press, Oxford, U.K.

Blouin, M. S., M. Parson, V. Lacaille, and S. LotZ. 1995. Use of microsatellite loci to classify individuals by relatedness. Molecular Ecology 5:393-401.

Campbell, T. S., and A. C. Echternacht. 2003. Introduced species as moving targets: Changes in body sizes of introduced lizards following experimental introductions and historical invasions. Biological Invasions 5:193-212

Castellano, S., and C. Giacoma. 1998. Morphological variation of the green toad, Bufo viridis, in Italy; a test of causation. Journal of Herpetology 32:540-550.

Clegg, S. M., S. M. Degman, J. Kikkawa, C. Moritz, A. Estoup, and I. P. F. Owens. 2002. Genetic consequences of sequential founder events by an islandcolonizing bird. Proceedings of the National Academy of Science of America 99:8127-8132.

El Mousadik, A., and R. J. Petit. 1996. High level of genetic differntiation for allelic richness among populations of the argan tree [Argania spinosa (L.) Skeels] endemic to Morocco. Theoretical and Applied Genetics 92:832-839.

Goudet, J. 2002. Fstat, a program to estimate and test gene diversities and fixation indices (Version 2.9.3.2). Available from: http:/www2.unil.ch/popgen/softwares/ fstat.htm.

Garza, J. C., and E. G. Williamson. 2001. Detectin of reduction in population size using data from microsatellite loci. Molecular Ecology 10:305-318.

Grant, B. R. 2003. Evolution in Darwin's Finches: A review of a study in Isla Daphne Major in the Galápagos Archipelago. Zoology 106:255-259.

Grant, P. R. 1998. Patterns on islands and microevolution. Pp. 1-17. In P. R. Grant (Ed.), Evolution on Islands. Oxford University Press, Oxford, U.K.

Grant, P. R. 2001. Reconstructing the evolution of birds on islands: $100 \mathrm{yr}$ of research. Oikos 92:385-403.

Hartl, D. L., and A. G. Clark. 1997. Principles of Population Genetics. Sinauer Associated, Inc., Sunderland, Massachusetts, U.S.A. 
Lampert, K. P., A. S. Rand, U. G. Mueller, and M. J. Ryan. 2003. Fine-scale genetic pattern and evidence for sex-biased dispersal in the túngara frog, Physalaemus pustulosus. Molecular Ecology 12:3325-3334.

Lampert, K. P., X. E. Bernal, A. S. Rand, U. G. Mueller, and M. J. Ryan. 2006. No evidence for female mate choice based on genetic similarity in the túngara frog Physalaemus pustulosus. Behavioral Ecology and Sociobiology 59:796-804.

Leberg, P. L. 1990. Influence of genetic variability on population growth: Implications for conservation. Journal of Fisheries Biology 37:193-196.

Leberg, P. L. 1992. Effects of population bottlenecks on genetic diversity as measured by allozyme electrophoresis. Evolution 46:477-494.

Lesbarrères, D., C. R. Primmer, A. Laurila, and J. Merilä. 2005. Environmental and population dependency of genetic variability-fitness correlations in Rana temporaria. Molecular Ecology 14:311-323.

Liedloff, A. 1999. Mantel Version 2.0 Mantel nonparametric test calculator. Available from: http:// www.sci.qut.edu.au/NRS/Mantel.htm.

Mayr, E. 1963. Animal Species and Evolution. Harvard University Press, Cambridge, Massachusetts, U.S.A.

Piry, S., G. Luikart, and J. M. Cornuet. 1999. Bottleneck: A computer program for detecting recent reductions in the effective population site using allele frequency data. Journal of Heredity 90:502-503.

Pröhl, H., R. M. M. Adams, U. G. Mueller, A. S. Rand, and M. J. Ryan. 2002. Polymerase chain reaction primers for polymorphic microsatellite loci from the túngara frog Physalaemus pustulosus. Molecular Ecology Notes 2:341-343.

Pröhl, H., R. A. Koshy, U. G. Mueller, A. S. Rand, and M. J. Ryan. 2006. Geographic variation of genetic and behavioral traits in Northern and Southern Túngara frogs. Evolution 60:1669-1679.

Pruett, C. L., and K. Winker. 2005. Northwestern song sparrow populations show genetic effects of sequential colonization. Molecular Ecology 14:1421-1434.

Queller, D. C., and K. F. Goodnight. 1989. Estimating Relatedness using Genetic Markers. Evolution 43:258275.

Reh, W., and A. Seitz. 1990. The influence of land use on the genetic structure of populations of the common frog Rana temporaria. Biological Conservation 54: $239-249$

Robinson-Wolrath, S. I., and I. P. F. Owens. 2003. Large size in an island-dwelling bird: Intraspecific competi- tion and the Dominance Hypothesis. Journal of Evolutionary Biology 16:1106-1114.

Ryan, M. J. 1985. The Túngara Frog, a Study in Sexual Selection and Communication. University of Chicago Press, Chicago, Illinois, U.S.A.

Ryan, M. J. 1998. Sexual Selection, Receiver Biases, and the Evolution of Sex Differences. Science 281:1999-2003.

Ryan, M. J., And A. S. Rand. 2003. Mate recognition in túngara frogs: A review of some studies of brain, behavior, and evolution. Acta Zoologia Sinica 49:713726.

Ryan, M. J., S. A. Rand, and L. A. Weigt. 1996. Allozyme and Advertisement Call Variation in the Túngara Frog, Physalaemus pustulosus. Evolution 50:2435-2453.

Schneider, S., D. Roessli, and L. Excoffier. 2000. Arlequin, Version 2000: Software for Population Genetic Data Analysis. Genetics and Biometra Laboratory, University of Geneva, Geneva, Switzerland.

Seppë, P., and A. Laurila. 1999. Genetic structure of island populations of the anurans Rana temporaria and Bufo bufo. Heredity 82:309-317.

Spencer, C. C., J. E. Neigel, and P. L. Leberg. 2000. Experimental evaluation of the usefulness of microsatellite DNA for detecting demographic bottlenecks. Molecular Ecology 9:1517-1528.

Tarr, C. L., J. D. Ballou, M. P. Morin, and S. Conant. 2000. Microsatellite variation in simulated and natural founder populations of the Laysan finch (Telespiza cantans). Conservation Genetics 1:135-146.

VAN VALEN, L. 1965. Morphological variation and width of ecological niche. American Naturalist 99: 377-390

WANG, Y., D. S. Williams, and M. S. Gaines. 2005. Evidence for a recent genetic bottleneck in the endangered Florida keys silver rice rat (Oryzomys argenatus) revealed by microsatellite DNA analyses. Conservation Genetics 6:575-585.

Weigt, L. A., A. J. Crawford, A. S. Rand, and M. J. Ryan. 2005. Biogeography of the túngara frog, Physalaemus pustulosus: A molecular perspective. Molecular Ecology 14:3857-3876.

Whittaker, R. J. 1998. Island Biogeography. Oxford University Press, Oxford, U.K.

Williamson-Natesan, E. G. 2005. Comparison of methods for detecting bottlenecks from microsatellite loci. Conservation Genetics 6:551-562.

Accepted: 13 April 2007 Associate Editor: Michael Harvey 